\title{
Serum amylase and lipase levels in type 2 diabetes mellitus
}

\author{
Noor-E-Jannat Tanvi' ${ }^{1}$, Qazi Shamima Akhter ${ }^{2}$, Sharmin Nahar ${ }^{3}$, Mahmuda Nasrin Sumi ${ }^{4}$, \\ Mobarak Hosen ${ }^{5}$
}

\begin{abstract}
Background: In diabetes mellitus, impaired pancreatic endocrine activity may affect its exocrine function causing mal digestion and malnutrition. Objective: To assess serum amylase and lipase levels in subjects with type 2 diabetes mellitus (T2DM). Methods: This cross sectional study was conducted in the Department of Physiology, Dhaka Medical College, Dhaka from January 2015 to December 2015. Fifty type 2 diabetic subjects with age ranging from 40 to 55 years of both sexes were enrolled in this study and 50 age matched healthy subjects were control group. Patients were enrolled from Outpatient Department of Endocrinology, Dhaka Medical College Hospital, Dhaka. Serum amylase and serum lipase levels were estimated by spectrophotometry. For statistical analysis, unpaired Student ' $t$ ' test was done. Results: In this study, serum amylase and lipase levels were significantly lower $(\mathrm{P}<0.001)$ in comparison to control group. Conclusion: From this study, it is concluded that, exocrine derangement of pancreas may occur in type 2 diabetes mellitus.
\end{abstract}

Key words: Serum amylase, serum lipase, type 2 diabetes mellitus.

J Bangladesh Soc Physiol. 2017, December; 12(2): 52-56 For Authors Affiliation, see end of text.

http://www.banglajol.info/index.php/JBSP

\section{Introduction}

D iabetes mellitus (DM) is a metabolic disease caused by either absolute insulin deficiency or impaired sensitivity of tissues to insulin ${ }^{1}$. Diagnostic criteria of diabetes mellitus are fasting blood glucose (FBG) $\geq 7.0 \mathrm{mmol} / \mathrm{L}$ or 2 hour after 75 gm glucose $\geq 11.1$ $\mathrm{mmol} / \mathrm{L}$ or Random blood glucose $(\mathrm{RBG}) \geq 11.1$ $\mathrm{mmol} / \mathrm{L}$ or gycosylated haemoglobin $\left(\mathrm{HbA}_{1 \mathrm{c}}\right) \geq$ $6.5 \%{ }^{2}$. Prevalence of diabetes in Bangladesh was 5.1 million in the year $2013^{3}$.

The pancreas is a mixed gland, with the exocrine portion making up the greatest volume of $84 \%$, while the endocrine part comprises $2 \%$ of it ${ }^{4}$. As there is a close anatomical and functional interaction prevails between these two portions

Received 28 August 2017; Accepted 10 Oct. 2017 of the pancreas, disease of one portion, may affect the other one $\mathrm{e}^{5,6}$. The exocrine acinar cells are exposed to high concentration of islet hormones as they receive blood flow coming through the nearby islets ${ }^{7}$. Evidence suggested that the pancreatic exocrine function is influenced by the pancreatic endocrine hormones specially insulin, which has a trophic effect on the exocrine acinar cells ${ }^{8}$.

The pancreatic exocrine acinar cells produce several types of enzymes including amylase and lipase that helps in digestion of particular food particles. Amylase is the primary enzyme responsible to cleave starch into maltose, maltotriose and $\alpha$-limit dextrins in the process of digestion. Lipase is primarily coming from pancreas, travels all the way down to the intestine 
and promotes breakdown of triglycerides into fatty acids and monoglycerides. Due to deficiency of pancreatic enzymes, foods are not properly digested and the consequences are mal digestion and malnutrition ${ }^{9}$. For many years, it has been thought that low serum amylase level reflects diffuse pancreatic damage due to advanced pancreatic disease. But now a days, several studies shown that this low level of serum amylase is also associated with metabolic syndrome and diabetes mellitus ${ }^{10}$.

A study investigating the effect of hyperglycemia on pancreatic exocrine functions in type 2 diabetic patients reported that serum amylase and lipase levels significantly increased with the regulation of glycemic control, but still lower as compared with control. They found a significant negative correlation of serum amylase and lipase with basal FBG and $\mathrm{HbA}_{1 \mathrm{c}}{ }^{11}$.

In diabetic patients, insulin resistance leads to an increase in the activity of anti-insulin hormones and atrophy of exocrine acinar cells. Thus, exocrine pancreatic enzyme synthesis and secretion is decreased ${ }^{12}$.The communication between the endocrine islets and the exocrine acinar cells were also lost with the development of type 2 diabetes mellitus. The pancreatic exocrine tissue becomes fibrosed and it shows a reduced response to the hormonal stimulation ${ }^{13}$. In diabetes mellitus, hyperglycemia and/or insulin inactivity due to hypoinsulinemia or insulin resistance may induce pancreatic exocrine dysfunction and the development of pancreatic exocrine insufficiency ${ }^{14}$.

Diabetic subject with pancreatic exocrine insufficiency commonly presents with gastrointestinal symptoms such as loose bowel movement, abdominal discomfort and flatulance ${ }^{15}$. In diabetes mellitus, this exocrine insufficiency can also give rise to deficiency of macronutrients, steatorrhoea and consequent malnutrition ${ }^{7}$.
In the human diabetic research of our country, very little concern has been given on exocrine pancreatic function, as less published data available regarding this topic. Majority of the studies focused the metabolic derangement due to impaired insulin action and persistent hyperglycemia. Therefore, the present study has been designed for evaluating exocrine pancreatic function by measuring serum amylase and lipase in type 2 diabetic subjects.

\section{Methods}

This cross sectional study was done in the Department of Physiology, Dhaka Medical College, Dhaka from January 2015 to December 2015. Protocol of this study was approved by Ethical review committee of Dhaka Medical College. For this study 50 diagnosed type 2 diabetic patients of both sexes with age ranging 40-55 years were selected as study group. They were selected from Outpatient Department of Endocrinology, Dhaka Medical College Hospital, Dhaka. Diagnosis was done by FBG level $\geq 7.0$ $\mathrm{mmol} / \mathrm{L}$ or $\mathrm{HbA}_{1 \mathrm{C}} \geq 6.5 \% \%^{2}$. Fifty age matched healthy subjects were considered as control for comparison. After selection, the nature, purpose and benefits of the study were explained to each subject andinformed written consent was taken from the participants. Before taking blood, detailed family and medical history were taken. Anthropometric measurement of the subjects was recorded and blood pressure was measured. All the information were recorded in a prefixed questionnaire. With aseptic precaution, $5 \mathrm{ml}$ of venous blood was collected from ante-cubital vein by a disposable plastic syringe from each subject for biochemical tests. FBG, serum amylase and serum lipase were estimated in the Department of Laboratory Services of National Institute of ENT, Dhaka. $\mathrm{HbA}_{1 \mathrm{C}}$ was estimated in the laboratory of the Department of Biochemistry of BSMMU, Dhaka. Data were expressed as Mean \pm SE. For statistical analysis unpaired Student's ' $t$ ' test and Pearson's correlation coefficient $(r)$ test were done.The $\mathrm{P}$ 
value of $<0.05$ was accepted as level of significance. Statistical analysis was performed by using a computer based statistical program SPSS (version 22).

\section{Results}

General characteristics are presented in Table I. There were no significant differences in any variables between study group and control.

Table I: General characteristics of the subjects in both groups $(\mathrm{n}=100)$

\begin{tabular}{lcc}
\hline Variables & $\begin{array}{c}\text { Control } \\
(\mathrm{n}=50)\end{array}$ & $\begin{array}{c}\text { Diabetics } \\
(\mathrm{n}=50)\end{array}$ \\
\hline Age (years) & $45.64 \pm 0.59$ & $47.06 \pm 0.65$ \\
Male no.(\%) & $24(48.0 \%)$ & $22(44.0 \%)$ \\
Female no.(\%) & $26(52.0 \%)$ & $28(56.0 \%)$ \\
BMI $\left(\mathrm{kg} / \mathrm{m}^{2}\right)$ & $25.77 \pm 0.50$ & $25.77 \pm 0.58$ \\
Systolic BP $(\mathrm{mmHg})$ & $116.20 \pm 1.41$ & $122.70 \pm 1.75$ \\
Diastolic BP $(\mathrm{mmHg})$ & $76.40 \pm 1.08$ & $78.70 \pm 1.07$ \\
\hline
\end{tabular}

Sex distribution has been shown in number and percentage. All other results are expressed as mean $\pm \mathrm{SE}$. Unpaired Student's ' $t$ ' test was performed for comparison between groups. $n=$ number of subjects.

Mean serum amylase and lipase were significantly $(\mathrm{p}<0.001)$ lower in type 2 diabetic patients (study group) compared to those of control (Table II).

Table II: Serum amylase and serum lipase levels of the subjects in both groups $(n=100)$

\begin{tabular}{lcc}
\hline Variables & $\begin{array}{c}\text { Control } \\
(\mathrm{n}=50)\end{array}$ & $\begin{array}{c}\text { Diabetics } \\
(\mathrm{n}=50)\end{array}$ \\
\hline Serum amylase (U/L) & $56.37 \pm 1.84$ & $33.37 \pm 2.36^{* * *}$ \\
Serum lipase (U/L) & $29.34 \pm 0.43$ & $21.58 \pm 1.69^{* * *}$ \\
\hline
\end{tabular}

Data were expressed as mean \pm SE. Unpaired Students ' $t$ ' test was performed for comparison between groups. $* * * \mathrm{p}<0.001$

This study showed that $28 \%$ subjects with type 2 DM had serum amylase level $<23 \mathrm{U} / \mathrm{L}$ (Figure 1) and $100 \%$ of subjects had serum lipase level $<5$ $\mathrm{U} / \mathrm{L}$ (Figure 2).

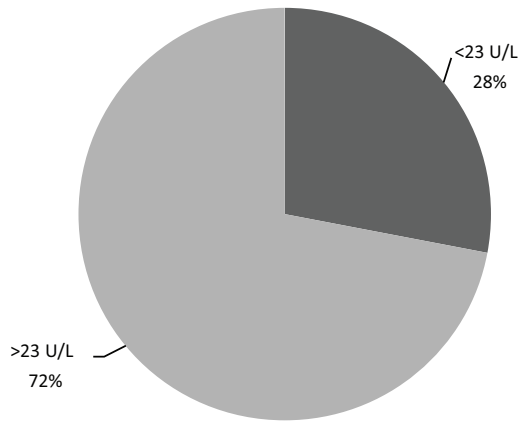

Figure 1: Frequency distribution of serum amylase level in study group $(\mathrm{n}=50)$

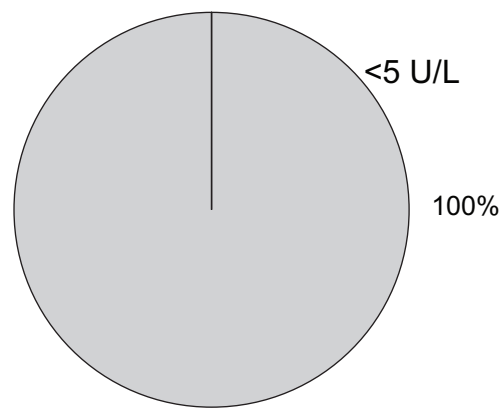

Figure 2: Frequency distribution of serum lipase level in study group $(\mathrm{n}=50)$

Correlation analysis showed significant negative correlation between serum amylase level and duration of disease in study group (Figure 3). This study also showed negative correlation between serum lipase level and duration of disease in study group (Figure 4).

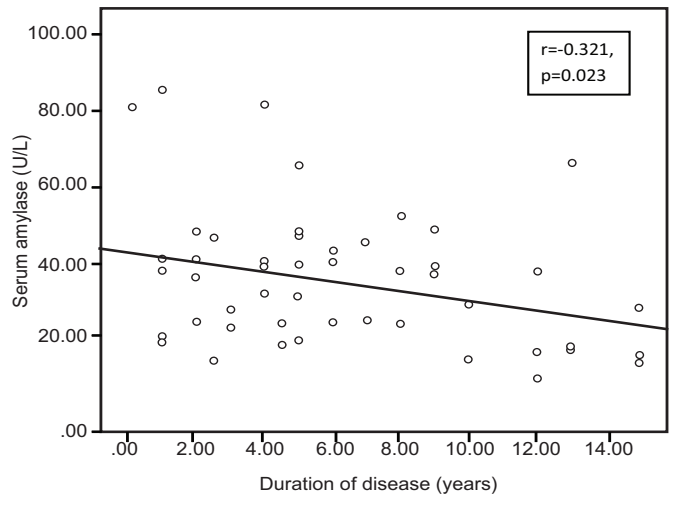

Figure 3: Correlation of serum amylase level with duration of disease in study group $(n=50)$. Correlation was done by Pearson's correlation coefficient test. 


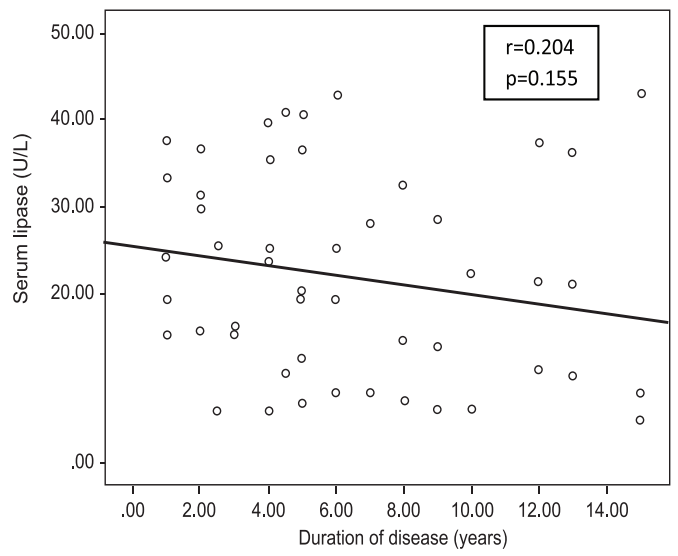

Figure 4: Correlation of serum lipase level with duration of disease in study group $(n=50)$. Correlation was done by Pearson's correlation coefficient test.

\section{Discussion}

In this study, the mean serum amylase level was significantly lower in type 2 diabetic patients than that of adult healthy subjects. This finding was in agreement with results of some workers $6,11,16,17,20-22$. On the contrary, some researchers found serum amylase level was significantly higher in type 2 diabetic subjects ${ }^{23,24}$.

In the present study, mean serum lipase level was significantly lower in type 2 diabetic subjects than that of adult healthy subjects. Similar type of observations was found by some researchers ${ }^{11,21,22}$. But some investigators found higher serum lipase level in type 2 diabetic subjects $^{23}$.

In this study, serum amylase and lipase levels showed negative correlation with duration of disease in study group. The relationship between serum amylase and duration of disease was statistically significant.Similar finding was also made by other research workers ${ }^{20}$. Amylase in type 2 diabetic subjects became more severely affected in long-standing cases of diabetes mellitus ${ }^{16}$.

Literature review suggested that in diabetes mellitus, hyperglycemia may cause cellular damage of the exocrine pancreas and leads to impaired synthesis of pancreatic digestive enzymes ${ }^{11}$. Some authors suggested that, hyperglycemia can cause disturbance in cellular signaling that controls both transcription and protein metabolism in the pancreas leading to pancreatic exocrine insufficiency in $\mathrm{DM}^{25}$.

\section{Conclusion}

From the results of the study, it may be concluded that, lower serum amylase and lipase levels in T2DM may be associated with the derangement of exocrine-endocrine axis leading to impaired exocrine pancreatic function.

\section{Conflict of Interest: None}

\section{Acknowledgment}

The authors acknowledge the Department of Endocrinolog of Dhaka Medical College, the Department of Laboratory Services of National Institute of ENT and the Department of Biochemistry of BSMMU, Dhaka, for their kind co-operation during sample collection and analysis.

\section{Author Affiliation}

1. *Noor-E-Jannat Tanvi, Lecturer, Department of Physiology, Shaheed Suhrawardy Medical College, Dhaka. email: dr.nj.tanvi@gmail.com. Cell :+88 01712200914

2. Qazi Shamima Akhter, Professor and Head, Department of Physiology, Dhaka Medical College, Dhaka. email: shamimaquzi@yahoo.com

3. Sharmin Nahar, Lecturer, Department of Physiology, Dhaka Medical College, Dhaka. email: taharat 30ishmam@gmail.com.

4. Mahmuda Nasrin Sumi, Assistant Professor, Department of Physiology, Jahurul Islam Medical College, Bajitpur, Kishoregonj. email: mahmuda_sumi00@yahoo.com.

5. Mobarak Hosen, Officer on Special Duty (OSD), Directorate General of Health Services, Ministry of Health and Family Welfare, Dhaka. email: drjamilkmc10@gmail.com.

*For correspondence

\section{References}

1. Hall JE. Insulin, Glucagon, and Diabetes Mellitus. In: Hall JE, editor. Guyton and Hall Text Book of Medical Physiology. $13^{\text {th }}$ ed. Philadelphia 
Pennsylvania; Saunders publications: 2011. p.983 - 999.

2. Seino Y, Nanjo K, Tajima N, Kodawaki T, Kashiwagi A, Araki E et al. Report of the committee on the classification and diagnostic criteria of diabetes mellitus. J Diabetes Invest. 2010; 1(5): 212-8.

3. Guariguata L, Whiting DR, Hambleton I, BeagleyJ, LinnenkampU, Shaw JE. Global estimates of diabetes prevalence for 2013 and projections for 2035 . Diabetes Res Clin Pract. 2014 Feb; 103(2):13749.

4. Singh J, Yago MD, Adeghate E. The role of insulin, glucagon, somatostatin, cholecystokinin, acetylcholine and nerve stimulation in the interactions between the endocrine and exocrine pancreas in normal and diabetic conditions in rats. Int J Diabetes 1999; 7(1): 114-9.

5. Pap Á. Effect of insulin and glucose metabolism on pancreatic exocrine function. Int $J$ Diabetes and Metabolism 2004; 12(3): 30-4.

6. Jain R, Jain PK, Mangukiya K. Study of serum amylase in the patients of type 2 diabetes mellitus. IJSN. 2014; 5(3): 553-6.

7. Chakraborty PP, Chowdhury S. A Look Inside the Pancreas: The "Endocrine-Exocrine Cross-talk". Endocrinol Metab Synd. 2015; 4: 1.

8. Barreto SG, Carati CJ, Toouli J, Saccone GTP. The islet-acinar axis of the pancreas: more than just insulin. Am J Physiol Gastrointest Liver Physiol. 2010 Jul; 299(1):G10-22.

9. Barrett KE, Barman SM, Boitano S, Brooks HL. Ganong's review of medical physiology. $24^{\text {th }}$ ed. New Delhi: Tata McGraw-Hill. 2012. Chapter 26, Digestion, Absorption and Nutritional Principles; 477-495p.

10. Nakajima K, Nemoto T, Muneyuki T, kakei M, Fuchigami $\mathrm{H}$, Munakata $\mathrm{H}$. Low serum amylase in association with metabolic syndrome and diabetes: A community-based study. Cardiovasc Diabetol. 2011; 10: 34 .

11. Ata N, Dal K, Kucukazman M, Yeniova AO, Karakaya S, Unsal O et al. The effect of glycemic control on CEA, CA 19-9, amylase and lipase levels. Open Med. 2015; 10: 8-13.

12. Demir K. Pancreatic dyspepsia: a place for pancreatic insufficiency in dyspepsia. Eur J Surg Sci. 2012; 3(1): 1-4.

13. Hayden MR, Patel K, Habibi J, Gupta D, Tekwani SS, Whaley-Connell A et al. Attenuation of endocrine-exocrine pancreatic communication in type 2 diabetes: pancreatic extracellular matrix ultrastructural abnormalities. J Cardiometab Syndr. 2008; Fall 3(4): 234-43.

14. Nakajima K, Oshida H, Muneyuki T, Kakei M. Pancrelipase: an evidence-based review of its use for treating pancreatic exocrine insufficiency. Core Evid. 2012; 7: 77-91.

15. Cummings M. Pancreatic exocrine insufficiency in type 1 and type 2 diabetes - more common than you think?. J of Diabetes Nurs. 2014; 18: 320-3.

16. Aughsteen AA, Abu-Umair MS, Mahmoud SA. Biochemical analysis of serum pancreatic amylase and lipase enzymes in patients with type 1 and type 2 diabetes mellitus. Saudi Med J. 2004; 26(1): 73-7.

17. Yadav R, Bhartiya JP, Verma SK, Nandkeoliar MK. The Evaluation of Serum Amylase in the Patients of Type 2 Diabetes Mellitus, with a Possible Correlation with the Pancreatic Functions. J of Clin and Diagn Res. 2013; 7(7): 1291-4.

18. Srihardyastutie A, Soeatmadji DW, Fatchiyah, Aulanni'am. Relation of elevated serum lipase to Indonesian type 2 diabetes mellitus progression. Biomed Res. 2015; 26(2): 293-8.

19. Mahmoud GMG, Ahmed SM. Assessment of plasma Alpha amylase level in Sudanese with type 2 diabetes mellitus. J Sci Technol. 2013; 14: 65-70.

20. Ewadh MJ, Juda TM, Ali ZA, Ewadh MM. Evaluation of amylase activity in patients with type 2 daibetes mellitus. Am J of Biosci 2014; 2(5): 171-4.

21. Ravisekar P, Selvi VSK, Devi AJM, Shanthi B. Study of serum pancreatic enzymes in patients with type 2 diabetes mellitus. Res J Pharm Biol Chem Sci 2015; 6(6): 144-6.

22. Ure O, Ata N, Kucukazman M, Tutal E, Caglar F, Hokkaomeroglu $M$ et al. Glycemic control influences CA19-9, CEA and ferritin levels in type 2 diabetes. presented at society of endocrinology IECE 2012, Florance,Italy,endocrine abstracts 2012;29: P512. [Internet] available from:http:// www.endocrine-abstracts.org/ea/0029/ ea 0029 p $512 . h t m$

23. Farhood HB, Al-salih RMH, Radhi MN. Clinical studies to evaluate pancreatic functions in the patients of type 2 diabetes mellitus. IJIAS 2014; 7(1): 413-20.

24. Abdelsalam KEA. Lipoprotein lipase, amylase and triglyceride alteration: lean diabetic and obese (nondiabetic) patients. IJSBAR 2015; 23(2): 95-103.

25. Patel R, Atherton P, Wackerhage H, Singh J. Signaling protein associated with diabetic-induced exocrine pancreatic insufficiency in rats. Ann N Y Acad Sci 2006 Nov; 1084:490-502. 